\title{
Impact of the 2012 Flood on Water Quality and Rural Livelihood in the Orashi Province of the Niger Delta, Nigeria
}

\author{
Prince Chinedu Mmom ${ }^{1}$ \& Pedro E. Aifesehi ${ }^{2}$ \\ ${ }^{1}$ Centre for Disaster Risk Management \& Development Studies, Department of Geography \& Environmental \\ Management, University of Port Harcourt, Choba, Port Harcourt, Nigeria \\ ${ }^{2}$ Department of Geography \& Environmental Management, University of Port Harcourt, Choba, Port Harcourt, \\ Nigeria \\ Correspondence: Prince Chinedu Mmom, Centre for Disaster Risk Management \& Development Studies, \\ Department of Geography \& Environmental Management, University of Port Harcourt, P. M. B 5323 Choba, \\ Port Harcourt, Nigeria. Tel: 234-803-338-9632. E-mail: pcmmom@yahoo.com
}

Received: July 19, 2013 Accepted: August 19, 2013 Online Published: August 21, 2013

doi:10.5539/jgg.v5n3p216 URL: http://dx.doi.org/10.5539/jgg.v5n3p216

\begin{abstract}
Flood event is not considered to be a natural hazard unless there is a threat to human life and/or property as the case of the 2012 flood incident in most parts of the Niger Delta, Nigeria. Thus, this paper aims at assessing the impact of the flood on groundwater quality of the affected areas, as well as the livelihood of the affected rural people. With a focus on six communities in the ORASHI province of the Niger Delta, which is one of the worst hit by the flood, the authors generated and analysed data that was used to draw conclusion for this study. A total of 2 water boreholes and 3 open artisan wells in each of the six (6) communities were sampled. These samples were subjected to both physico-chemical and microbial analysis against WHO standards. The result shows that the various water samples came short of the WHO Standards for safe water. Thus it could be deduced that the 2012 flood triggered damages not only to the life of individuals, properties/ infrastructure, but also most of the drinking water sources, especially, streams and the dug-out wells which were submerged in the event of the flood. The paper discovered that the flood incident seriously devastated the rural economy; farming, the major source of livelihood. The flood has made livelihood support difficult for the people of the area. Thus, community initiated mitigation measures should be promoted so as to strengthen community resilience.
\end{abstract}

Keywords: flood, rural livelihood, hazard, Orashi, water quality, Niger Delta, vulnerable

\section{Introduction/Background}

Floods are defined as extremely high flows of river, whereby water inundates flood plains or terrains outside the water-confined major river channels. Flood hazard is measured by probability occurrence of their damaging values, conceived generally as flood risk, or by their impact on society, conceived usually as the loss of lives and material damage to society (Mwape, 2009).

Flood is a natural disaster and integral component of natural cycle which often happens in multitude of ways and inundates areas and communities as well. According to Nott (2006:51), the causes of floods can be broadly divided into physical, such as climatological forces, and human influences such as vegetation clearing and urban development. The most common causes of floods are climate related, most notably rainfall. Prolonged rainfall events are the most common cause of flooding worldwide. These events are usually associated with several days, weeks or months of continuous rainfall. This natural phenomenon as a part of the earth's bio-physical processes becomes devastating due to human anthropogenic activities such as clearing of vegetation, intervention in natural drainage lines, deforestation and permanent occupancy of wetlands in the buffer zones of riverbank ecosystem and in some cases, flood occurs when dams fail thereby releasing large and uncontrolled volume of water. Thus, floods are acts of God, but flood losses are largely acts of man. Human impacts on river catchments influence flood behavior. Land use changes in particular have a direct impact on the magnitude and behavior of floods. Deforestation results in increased run-off and often a decrease in channel capacity due to increased sedimentation rates. Nott (2006:54) correctly points out that a flood event is not considered to be a natural hazard unless there is a threat to human life and/or property. The most vulnerable landscapes for floods are low-lying parts of flood plans, low-lying coasts and delta s, small basins subject to flash floods. Rivers offer human populations transport links, a 
water source, recreational amenities, fertile plains and are an attractive place for settlements. Floods then become a major natural hazard because of the high human population densities that inhabit these lands. He indicated that the direct impacts of a flood are closely related to the depth of inundation of floods water.

According to the IPCC Special Report (2007) on the Regional Impacts of Climate Change, there would be drastic changes in rainfall patterns in the warmer climate and coastal regions as the Niger Delta may experience 5-6\% increase of rainfall by 2030, which may create frequent high and prolonged floods in the region. Seasonal flood hazards reduced livelihood opportunities, household income and employment of the affected rural dwellers. Farm-based wage labourers and farmers were seriously affected from seasonal flood hazards. No conscious effort was taken in the past aiming at true development of life and livelihood of the Niger Delta people, who have always remained excluded from the main stream. However, the flood hazard remains hazard without becoming disaster if vulnerability is reduced through some preparations and actions (Mmom \& Aifesehi, 2013).

The extent of a flood has a direct relationship for the recovery times of crops, pastures and the social and economical dislocation impact to populations. Floods are the most costly and wide reaching of all natural hazards. They are responsible for up to 50,000 deaths and adversely affect some 75 million people on average worldwide every year. Disease outbreak is common especially in less developed countries. Malaria and Typhoid 18 outbreaks after floods in tropical countries are also common. It has been estimated that in India and Bangladesh 300 million people live in areas that are affected by floods (Nott 2006:57).

Nott (2006:60) further stated that physical damage to property is one of the major causes for tangible loss in floods. This includes the cost of damage to goods and possessions, loss of income or services in the floods aftermath and clean-up costs. Some impacts of floods are intangible and are hard to place a monetary figure on. Intangible losses also include increased levels of physical, emotional and psychological health problems suffered by flood-affected people. Due to flood topography, unpredictable climatic hazards, uncontrolled cross-boundary flood water, subsistence agro-based livelihood and poor economic conditions, it is highly needed to follow community level adaptation practices and preparedness compare to large-scale structural measures.

It is a truism that there is s considerable reduction or alteration in water quality in the event of extreme floods. The poor quality of water may be due to huge amount of man-made and natural contaminants and erosion. Man has altered low lying areas to farmlands by considerable removal of floodplain vegetation and wetland regions which serve as sediment intercept, hydraulic sponges, natural stilling ponds and erosion protection (Saeed \& Attaullah, 2013). Besides all these, surface flows (runoffs) have been a source of unwanted chemicals including heavy metals in the water on surface. Submerged sewage and industrial sites like wastewater treatment plants, chemical processing and manufacturing centers, and disposal or holding areas serve as point sources for chemical contamination of water, while runoff from agricultural land is the main non-point pollution origin. Large amounts of herbicides and nitrate were transported from urban and agricultural areas during the ruinous Mississippi River basin flood of 1993 (Goolsby, Battaglin, \& Thurman, 1993). Goolsby et al. (1993) also compared 1992 and 1993 loads at the Mississippi mouth and noticed a 235 percent increase in the load of atrazine herbicide used in corn production and a 112 percent increase in the load of nitrate. Short- and long-term adverse climatic impacts can result from chemical loading and poor quality water (Saeed \& Attaullah, 2013). Goolsby et al. (1993) cited Michael Dowgiallo of the National Oceanic and Atmospheric Administration affirmed that the chemical loads were promoting primary production which caused an elevation in the levels of marine phytoplankton in the Gulf of Mexico. Zooplanktons, being a potent part of aquatic food chains, consume phytoplanktonic algae and provide a forage base for higher predators but this may cause adverse algal peaks.

Know Risk (2005:74) observed that studies undertaken show that the economic impact of natural disasters, such as flood shows a marked upward trend over the last several decades. The hazards tend to hit communities in developing countries especially the least developed countries, increasing their vulnerability and setting back their economic and social growth, sometimes by decades. The floods have led to loss of human life, destruction of social and economic infrastructure and degradation of already fragile ecosystems. The study indicates that social impacts include changes in people's way of life, their culture, community, political systems, environment, health and wellbeing, their personal and property rights and their fears and aspirations. The study undertaken in Scotland suggests that social impacts are linked to the level of well being of individuals, communities and society. It includes aspects related to the level of literacy and education, the existence of peace and security, access to basic human rights, systems of good governance, social equity, positive traditional values, knowledge structure, customs and ideological beliefs and overall collective organizational systems. In the event of floods, socioeconomic life and livelihood of the affected people are distorted. In most cases farmlands and livestock are submerged which are the major source of the people's livelihood. Property worth millions of dollars are lost in the event of flood and in most cases the people are displaced for several weeks, only to return home to start life afresh. Flood losses 
are devastating as many never get recovered after the flood recedes. Vulnerable communities suffer great losses in events of flood, especially when the flood is unprecedented. Hunger, famine, diseases and epidemics outbreak are usually resultant impact of flood (Mmom \& Aifesehi, 2013).

Moreso, it is a truism that when flood disaster occurs, government and other non-governmental agencies come to the aid of the victims through relocation into refugee camps and provision of relief materials. However, a common experience, especially in the developing countries is the outbreak of epidemic diseases due to poor sanitary conditions of the camps. This health challenge continues and become worse when the camps are closed and people return home to begin life afresh. In most cases, the relief materials such as water, toiletries, food and medication cease to flow in and the people have to contend with whatever they can find at their disposal. The highly polluted water becomes the available option for domestic water need.

\section{The Problematic}

Natural hazard of flood is not new to the people of Niger Delta as they have been living in flood-prone areas for centuries-in some cases thousands of years. They have inevitably, devised their own methods for protecting themselves and their livelihoods against flood hazards, however, the 2012 flood in the region was the first of its kind the past three (3) decades. The flood height rose up to 3.2 metres in certain places with very swift flow or velocity, sweeping away both lives and properties. The OrashiI province of the Niger Delta was one of the worst hit victims of the 2012 floods in Nigeria. Although not a very coastal region (see Figure 1), but it is deltaic and traversed by several rivers systems which naturally makes them vulnerable to flood disaster.

The region, with a population of over 3.8 million plays a very important role in the economy of the Niger Delta. It has over $35 \%$ of the oil wells in the Niger Delta, Nigeria. Apart from oil, it is an agricultural region with both crop cultivation and fishing as major occupation of the people and source of livelihood. Some of the farm produce from the area include, plantain, yam, cocoa- yams, banana, and potatoes. They equally engage in fishing, lumbering and harvesting of other non-timber forest products as, snails, fishes, canes, honey and hunting of bush animals which are native delicacies.

However, the 2012 flood in the region that took a different dimension as it was not ordinarily caused by rise in sea-level due to excessive rainfall, but from overflow of River Benue as a result of collapse of dam at the upper course of the River in the Cameroun republic resulted in unprecedented damage to the local economy. The flood as described by so many eye-witnesses and reporters was the worst in the past three decades and lasted for about 5 weeks. It was characterized by high tidal flow, with an average height of 2.4 meters, thereby submerging many communities and leading to the evacuation and relocation of the people for several weeks. Public infrastructure as road, electricity, telecommunication, buildings were feared to have been destroyed in course of the flood. If one portrays the trail of devastations that took place due to 2012 flash floods in all over the country, the noticeable and serious damages can be seen in the ORASHI province of the Niger Delta (see Plate 1, 2 \& 3).

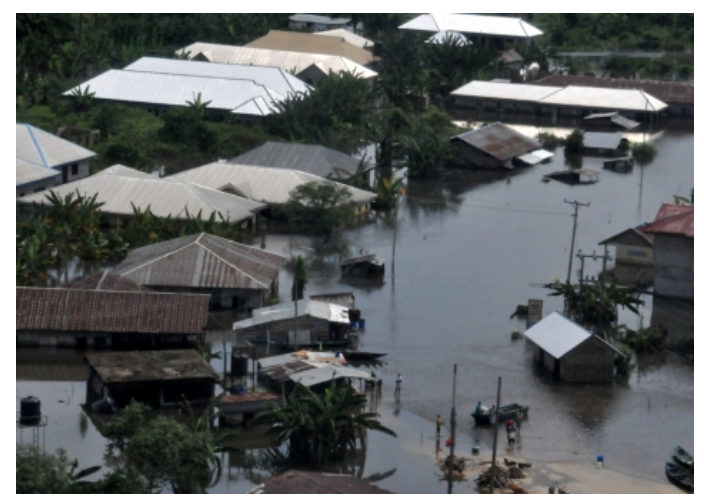

Plate 1. Submerged community during 2012 flood

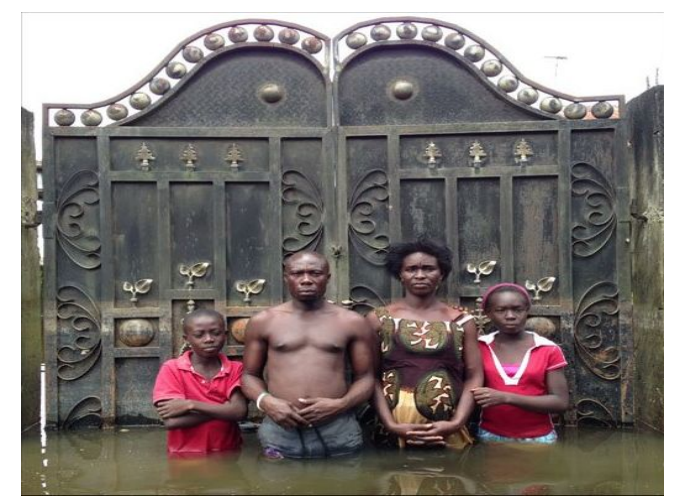

Plate 2. Family lost home \& properties 


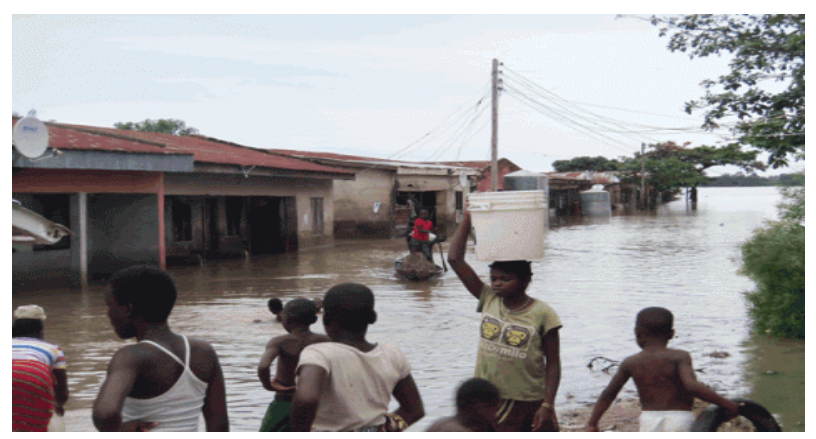

Plate 3. Flooded road in a community

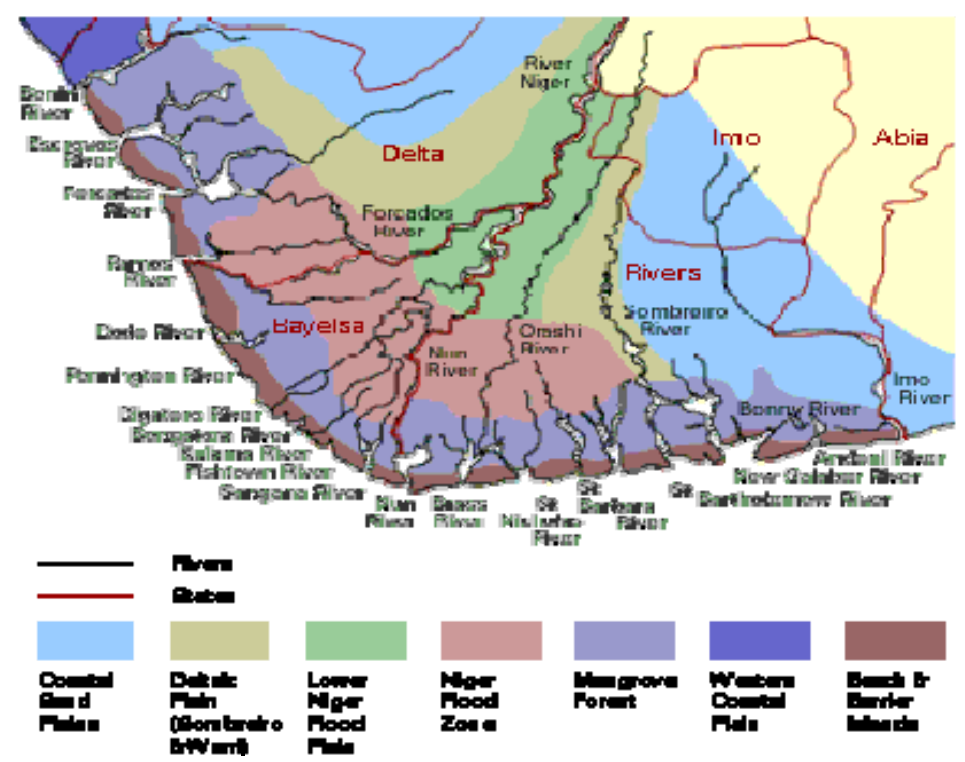

Figure 1. Map of the Niger Delta showing Orashi

After the flood receded, Government and many organizations had an immediate focus on damages to properties, and infrastructures in response to the flood damages assessment, emergency rescue and rehabilitation but the environmental impacts on rural livelihood and resilience were neglected. This worst flood triggered damages not only to the life of individuals and destroyed infrastructure but also most of the drinking water sources, especially, streams and the dug-out wells which were submerged in the event of the flood. In effect, the submergence of these water sources made it difficult for the flood affected population to find potable and safe water for drinking and other domestic purposes. The flood has also made livelihood difficult for the people. Thus, this paper aims at assessing the impact of the flood on groundwater quality of the affected area. Also, to assess the impact it has had on the livelihood of the affected rural people as well as their resilience in the event of future occurrence. Against the foregoing background, the following questions become fundamental at this point and providing answers to them form the focus of interest of this paper: Has the 2012 flood any impact on the groundwater quality of the affected communities? What is the extent of groundwater quality alteration? What is the amount of economic losses associated with the flood? To what extent has this affected livelihood of the affected people? What roles did government play in making the people resilient to the flood disaster? How prepared or resilient are the people in the event of future flood events?

\section{Methodology of Study}

The 2012 flood in parts of Niger Delta Nigeria could be described as one of the greatest in the country in the past two decades. The flood which surprisingly did not affect the coastal communities, but rather the hinterlands affected most parts of the Niger Delta states and for this study, focus was on the ORASHI region of Rivers State, who could be described as the hardest hit by the unprecedented flood.

For water quality assessment of flood impact, water samples were drawn/collected from water sources in six (6) communities in the Orashi region of Rivers State, namely: Odiabidi, Joinkrama, Okogbee, Ede, Oboburu, 
Aminigboko. Basically, two (2) boreholes and three (3) open artisan wells in each of the six (6) communities were sampled, giving a total of 30 samples. The choice of more Artisan wells was because majority of the inhabitants are dependent on groundwater from the wells and only a few boreholes were available / accessible to the local people.

Physico-chemicals analysis of 12 parameters were was carried out on each of the samples collected in 1.5 liters capacity (air-tight cap) fresh, clean and dry plastic bottles. Each bottle was clearly marked for identification of the location, date and period of collection and care was taken to avoid entrance of external materials in bottles during sample collection.

$250 \mathrm{ml}$ glass bottles were used for microbiological analysis of bacteriological contaminants. First, the bottles were cleaned with detergents and rinsed with distilled water. Then $5 \mathrm{ml}$ of Sodium thiosulfate in each glass bottle was taken and covered with air tight cap and was sealed with aluminum foil tightly. These bottles were placed in an oven for about 45 minutes at about $140^{\circ} \mathrm{C}$. Bottles were finally sterilized. After collecting samples at the site, bottles were kept in ice coolers to transfer it to the laboratory.

Both physical assessment and survey questionnaires were used to collect data on the impact of the flood on rural livelihood, especially in terms of estimate of crop and animal losses as well as income effect and sustenance. These data were tabulated and analysed using simple descriptive statistics.

\section{Data Presentation/Discussion}

Table 1 above shows the values of each of the 12 tested parameters across the 6 sample communities for the two domestic water sources in the study area. From the table, column 1 shows there is no significant variation in temperature across the samples. The warmer temperature of the samples could be accounted for by the time period when the study was carried out, that is, in December (the dry season). It is worthy of note here that temperature is one of the physical parameters of measuring water quality as it has significant effect on the both the chemical and biological characteristics of water.

In terms of the $\mathrm{pH}$ of the water samples, the analysis shows no significant variation among the various samples in the six communities. $50 \%$ of the samples have $\mathrm{pH}$ values within the WHO standard limits of between 6.5-8.0, while $50 \%$ were either below or above the standards. A critical look at the result shows that most of the samples that fall within the limit were from the boreholes, while the samples from the open wells show more deviation from the WHO limit. The explanation for this is the effect of the submergence of these open wells by the flood which carried many acidic and chemical compounds in solution and deposited inside these open water sources. $\mathrm{pH}$ is a water quality parameter which is used to evaluate the level of acidity or alkalinity of drinking water. Generally, high $\mathrm{pH}$ value causes corrosion of metallic pipes which is associated with serious health problems due to the presence of heavy metals in drinking water leached inside the pipe distribution systems through which it passes (Saeed \& Attaullah, 2013). WHO guidelines (2011) recommend a desirable limit of 6.5 to 8.0 for the pH of drinking water. A little variation from this range is usually not associated to health issues but the value ranging from 10 to 12.5 have been documented to cause swelling of hair fibers and skin problems, and stomach disorders. While inflammation of eyes has also been reported with $\mathrm{pH}$ lower (Johnbosco, 2011; Saeed \& Attaullah, 2013). However, as the Table 1 show, the variation from the WHO standards is not much as non exceeded 9.2 or less than 6 , but for one sample.

Good quality water for drinking must be clear and colourless. Thus turbidity measures the relative clarity and cloudiness of water. The presence of suspended colloidal particulates is responsible for the obstruction of transmission of light through water. The WHO recommended value of turbidity should ideally be less than 1 NTU for effective disinfection, but Table 1 above shows that none of the samples fall within the WHO limit. In fact there is a sharp departure from the standard as all the samples show high average value of 17 NTU. The open well indicated higher values than the boreholes, especially as they were not protected from the flood water with mixture of dissolved and suspended materials.

There exists a general relationship between Electrical Conductivity and Total dissolved solids (TDS) and Electrical Conductivity (EC). However, both tests were performed separately to get the precise values of both parameters. The analysis of data for these two parameters showed that the conversion factor for overall samples was close to a value of 0.7 . The desirable value of $600 \mathrm{mg} / \mathrm{l}$ for TDS is proposed by WHO (2011) on the basis of acceptability of drinking water. TDS with value higher than $1000 \mathrm{mg} / \mathrm{l}$ provide taste to the water and cause excessive scaling in pipes, heating units and boilers. From Table 1, column 5 above, TDS are higher in all the samples. All samples show higher values than desirable limit. Samples from the open wells show higher values of TDS than those from boreholes. These high values may be because of the runoff into these unprotected wells 
during the flood. The samples equally show a significant deviation from the WHO acceptable limit of 1000 $\mu \mathrm{Scm}^{-1}$ Electrical Conductivity.

Table 1. Physico-Chemical analysis of water samples from the six (6) communities

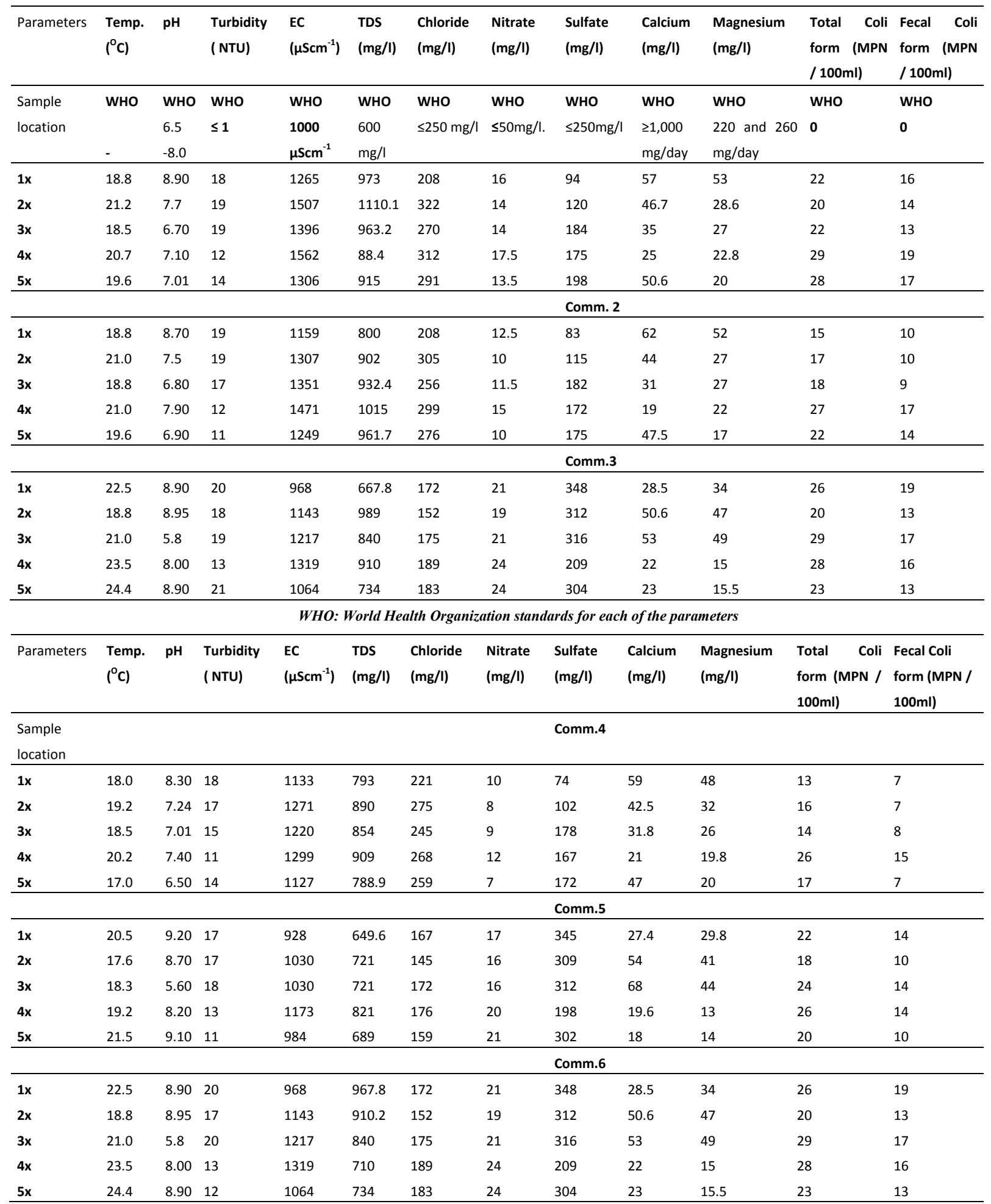


Analysis of chloride in the water samples show that 19 out of the 30 samples have chloride content within the WHO limit of less than $250 \mathrm{mg} / \mathrm{l}$; while 11 samples have chloride level above the WHO accepted value. Ideally, a pollutant-free fresh water should possess chloride content of less than $10 \mathrm{mg} / \mathrm{l}$, but WHO guidelines, stipulates chloride content less than $250 \mathrm{mg} / \mathrm{l}$ as good on the basis of acceptability for drinking since value higher than 250 $\mathrm{mg} / \mathrm{l}$ imparts considerable taste to drinking water and consumers may be uncomfortable to drink such water. Similarly, analysis of Nitrate level shows that all the samples analyzed fell within the WHO acceptable limit of $\leq 50 \mathrm{mg} / \mathrm{l}$. Higher level of nitrate ions may cause an unusual illness; ingestion of such water also affects health of pregnant women (Self \& Waskom, 2008).

According to WHO guidelines the desirable limit for sulfate ions in drinking water should be less than $250 \mathrm{mg} / \mathrm{l}$. Higher concentration level of sulfate imparts bitter taste and offensive odour (smell) to drinking water and causes scale in water pipes (Sharon et al. 2010) as quoted by Saeed and Attaullah (2013). Water with high content of sulfate causes severe dehydration and Diarrhea in every age of people. Young and old age people may become accustom using such water with the passage of time but care should be taken while using such water in the food preparation for infants (Saeed \& Attaullah, 2013).

Calcium and Magnesium are key nutrient for health, structure of bones, muscular contraction, cell signaling and blood clotting (Cotruvo, 2006). To avoid the chances of developing osteoporosis, nephrolithiasis and hypertension, it has been recommended that adequate consumption of calcium should be taken in daily dietary intake. In 2001, an expert consultant for the Food and Agricultural Organization (FAO) and WHO set recommended nutrient intakes (RNIs) for Calcium at 1,000 mg/day for women aged 19-50 and men aged 19-65 years, and 1,300 mg/day for women of age 51-65 years and intakes for Magnesium at 220 and $260 \mathrm{mg} / \mathrm{day}$ respectively for women and men aged 19-65 years old (Cotruvo, 2006). However, Water containing these two important and common minerals in high range is known as hard water and has low utility value. Although the table shows adequacy of calcium in the water sampled, but that of magnesium is far below the WHO recommendation. Thus, the water samples from these communities show gross deficiency in magnesium.

Total coliform bacteria are a group of bacteria generally present in the environment. Fecal coliform are a sub group of total coliform which are present in the human and animal feaces. The hefty flooding and increased precipitation in the study area increased the occurrences of total coliform bacteria in water. Since the wells of the study area are un-engineered, open and lacking of regular maintenance, submergence of wells and pipes in floods and rain water, open septic tanks and sewer systems and inadequate drainage systems, all these factors contributed to the presence of total coliform and fecal contamination at all sampling points and correspondently gave rise to infectious and serious water borne diseases. Any water to be used for intake or food preparation should be free of all such contamination. The flooded areas are more prone to water borne disease outbreaks. WHO guidelines recommended a value of Zero M PN per $100 \mathrm{ml}$ for total coliform as well as for fecal coliform bacteria, but the analyses in Table 1 shows a gross departure from the WHO standards. These microbial compounds are found in rich loads in all the water samples portraying high level of pollution from sewage as well as decomposition of organic material that would possibly have been killed by the flood.

\subsection{Livelihood Patterns}

Table 2. Major occupation/ source of livelihood

\begin{tabular}{llll}
\hline S/N & Major source of livelihood support & Frequency & Percentage (\%) \\
\hline 1 & Crop farming & 187 & 62 \\
2 & Trading & 43 & 14.3 \\
3 & Paid employment & 34 & 11.3 \\
4 & Others & 26 & 8.6 \\
& Total & 300 & $100 \%$ \\
\hline
\end{tabular}

Analysis of main livelihood source in the area in Table 2 above shows that $62 \%$ of the household heads depend on crop farming for living, while only about $14.3 \%$ are into trading as major livelihood support; $11.3 \%$ are engaged in paid employment and $8.6 \%$ are engaged in other employment activities. On a general note, the people have limited livelihood options as most of them indicated to have little or no significant secondary livelihood sources. 
Thus, a devastating flood as the case of the 2012 case would have rendered over $70 \%$ of the households hopeless as the agro-crops would have been lost in the flood. The local economy of the Orashi province is dependent on agricultural production. In other words, crop farming is the major occupation of the people, thus the 2012 flood that submerged $65 \%$ of the entire area would have had damaging effect on the people's source of livelihood.

Table 3. Damage to major agricultural crops in affected sample areas

\begin{tabular}{llllll}
\hline S/N & Agro-crops & $\begin{array}{l}\text { Area Damaged } \\
\text { (000 ha) }\end{array}$ & $\begin{array}{l}\text { Yield Loss } \\
\text { (tons/ha) }\end{array}$ & $\begin{array}{l}\text { Projected Production } \\
\text { Loss (hundred tons) }\end{array}$ & $\begin{array}{l}\text { Projected Loss in } \\
\text { monetary terms USD (\$) }\end{array}$ \\
\hline 1 & Cassava & 3.7 & 25.1 & 4.1 & $105,000.00$ \\
2 & Yams & 2 & 12.4 & 2.5 & $74,217.00$ \\
3 & Plantain & 1.46 & 19.1 & 3.7 & $102,000.00$ \\
4 & Banana & 1.14 & 14.9 & 1.4 & $53,0000.00$ \\
5 & Coco-yam & 0.54 & - & 0.7 & $5,000.00$ \\
6 & Potatoes & 1.52 & 5.7 & 0.9 & $7,000.00$ \\
\hline
\end{tabular}

Source: Fieldwork, 2013.

Table 3 above shows approximate loss of over 4 hundred tons of cassava production, amounting to about $\$ 105,000$. Similarly, plantain, which is another staple food produced in the province suffered a loss of about 19.1 hundred tons, valued at an estimate of $\$ 102,000.00$. Yams were also damaged at an estimate of 2.5 hundred tons estimated at $\$ 74,217$. This is followed by Banana, with about 1.4 hundred tons estimated at $\$ 53,000.00$; Potatoes with 0.9 hundred tons estimated at $\$ 7,000.00$ and Cocoa-yams with 0.7 hundred tons estimated at $\$ 5,000.00$.

This result shows gross loss of agricultural produce, income and livelihood source in the region as an effect of the devastating flood in the region. This finding corroborates with the assertion of Noth (2006) that the extent of a flood has a direct relationship for the recovery times of crops, pastures and the social and economical dislocation impact to populations. Local populations suffer great economic losses, some of which they never recover from for several years. This finding has provided better understanding of the vulnerability of the communities as a result of their over dependency on crop production as their main livelihood source.

Table 4. Coping strategies with past flood events

\begin{tabular}{lll}
\hline Raising of building DPC/ heights & 105 & $35 \%$ \\
Construction of houses with concrete structures & 231 & $51.3 \%$ \\
Construction of flood diversion trenches & 223 & $49.5 \%$ \\
Relocation/ Removable of moveable properties to nearest neighbours & 294 & $98 \%$ \\
Early planting/change in farming regime & 286 & $63.5 \%$ \\
\hline
\end{tabular}

Source: Fieldwork, 2013.

Table 4 analyses the coping strategies adopted by the people as past flood events. From the analysis above, about $35 \%$ of the people raised their Damp Proof Course (DPC) and building heights as an adjustment technique, 51\% constructed their houses with concrete structures; $49 \%$ constructed flood diversion trenches. Furthermore, about $98 \%$ changed their farming regime to early planting, while $63.5 \%$ relocated and moved their properties to their nearest kits and kin until the flood receded. However in the case of the 2012, flood, the people noted that it was the worst kind of as most buildings were even submerged to window and roof levels as could be seen in plate 2 and 3 above. 
Table 5. Level of preparedness of households for future flood events

\begin{tabular}{lll}
\hline Reponses & Frequency & $\mathbf{\%}$ \\
\hline Prepared & 126 & 42 \\
Not Prepared & 88 & 29.3 \\
Undecided & 86 & 28.6 \\
Total & $\mathbf{3 0 0}$ & $\mathbf{1 0 0}$ \\
\hline
\end{tabular}

Source: Fieldwork, 2013.

In Table 5 above on the level of preparedness for future flood events, the analysis shows that $42 \%$ of the people indicated that they are prepared to face any flood in the future, about $29 \%$ indicated that they are not prepared, while about $28 \%$ of the people are not sure whether they are prepared or not.

\section{Summary and Conclusion}

The study shows that the region is naturally vulnerable to flood and have suffered flooding in the past. However, the 2012 flood was described as the worst in the past 50 years and caused outrageous damages to properties and livelihood. The study found out that until the present, many of the people have not recovered from the flood losses. The local people seem to be resilient to flood hazard as they have coped with hazards in the past, but the 2012 flood was a disaster, making them both vulnerable and resilient at the same time.

Portable drinking water supply is discovered as a serious challenge in the region. This was affirmed by the results that the groundwater analysis which reveals that all the analysed water samples came short of the WHO Standards for safe water. The hand-dug wells is the primary source of water for domestic use in the region, but have been highly polluted after the flood and unfit for drinking purposes. Thus, it can be declared that floods cause a direct impact on environment and all its components. Impact of floods on water quality may not only cause diseases in humans, but may also destroy the aquatic life and hence disturb the complete natural cycle.

The study did not reveal any significant spatial variation in the quality of the ground water in the region. This could be as a result of homogeneous nature of the subsurface geology or because of it geographical contiguity. In terms of livelihood, the paper discovered that the flood incident seriously devastated the rural economy; farming, the major source of livelihood. Farmlands were submerged and agricultural produce were destroyed. Many of the people are yet to overcome the trauma and recover from the flood losses. On the premise of the findings of this study, it is recommended that the natural dynamics of floods should be investigated and wise and feasible policies should be formulated and strictly implemented. In order to make sure that environmental concerns are judiciously and properly represented in flood management decisions, individual cases must be assessed from a basin-wide perspective.

There is an intense need for environmentally sound and feasible arrangement of drinking water for people affected by floods as water quality becomes more unreliable when hit by floods.

Government and key Stakeholders should engage the communities and local authorities in making them aware of the flood risk in view of the climate variability.

Community initiated mitigation measures should be promoted so as to strengthen community resilience.

In the long term, community based floods early warning system should be developed.

The Niger Delta Basin Development Authority should consider aggressive construction of dams to trap the excess water.

There is need for further investigation (EIA) and reconsideration of the proposal for the dredging of River Niger.

\section{Acknowledgements}

The authors wish to express their appreciation to Tertiary Education Trust Fund (TETFUND) research grants 2012 of the Federal Government of Nigeria for providing part of the funding for this research. Also appreciated are the authors whose works were cited in this paper. We say thank you to Mr. Mbee Daniel Mbee for providing the maps that were used in this paper. 


\section{References}

Cotruvo, J. (2006). Health Aspects of Calcium and Magnesium in Drinking Water. (NSF/ILSI/WHO) in Baltimore, Md. 2006.

Goolsby, D. A., Battaglin, W. A., \& Thurman, E. M. (1993). Occurrence and transport of agricultural chemicals in the Mississippi River basin July through August 1993. Washington D. C.: U.S Geological Survey circular 1120-C, U. S. Government Printing Office,

Johnbosco, U. (n.d.). Water Quality near abattoir houses in Trans-Amadi Area of Port Harcourt Rivers State, Nigeria. Unpublished Technical Paper presented at Nigerian Environmental Society Round Table on Water Quality. Federal Secretariat Complex, Port Harcourt, Nigeria.

Know, R. (2005). United Nations (p. 74). Geneva, Switzerland.

Mmom, P. C., \& Aifesehi, P. E. E. (2013). Vulnerability of Niger Delta Coastal Communities to Flooding. Journal of Humanities and Social Science, 10(6), 27-33. http://dx.doi.org/10.9790/0837-1062733

Mwape, Y. P. (2009). An impact of Flood on Socio-economic Livelihoods of People: A Case study of Sikwaunezwe Community in Kazungula District of Zambia. Unpublished Seminar Paper, The University of the Free State

Nott, J. (2006). Extreme Events: A Physical Reconstruction and Risk Assessment (p. 51). New York: Cambridge University Press. http://dx.doi.org/10.1017/CBO9780511606625

Saeed, T. U., \& Attaullah, H. (2013). Impacts of Floods on Water Quality. British Journal of Environment and Climate Change (In press).

Self, J. R., \& Waskom, R. M. (2008). Nitrates in drinking water. Colorado State University. 2008. Retrieved from http://www.ext.colostate.edu/pubs/crops/00517.html/

Sharon, O. S., Bruce, I. D., \& Woldt, W. (2010). Drinking Water: Sulfur (Sulfate and Hydrogen Sulfide). University of Nebraska-Lincoln Institute of Agriculture and Natural resources. Retrieved from http://www.ianrpubs.unl.edu/epublic/live/g1275/build/g1275.pdf

WHO guidelines. (2011). Guidelines for drinking-water quality (4th ed.).

\section{Copyrights}

Copyright for this article is retained by the author(s), with first publication rights granted to the journal.

This is an open-access article distributed under the terms and conditions of the Creative Commons Attribution license (http://creativecommons.org/licenses/by/3.0/). 